\title{
EFFECT OF ALTITUDE AND WOUNDING ON BLOOD DISEASE PROGRESS OF PLANTAIN
}

\author{
Hadiwiyono $^{1}$, S. Subandiyah ${ }^{2}$, C. Sumardiyono ${ }^{2}$, J. Widada $^{2}$, \\ and M. Fegan ${ }^{3}$
}

\begin{abstract}
Effect of Altitude and Wounding on Blood Disease Progress of Plantain. In the latest decade, the blood disease of banana has spread in almost all provinces in Indonesia and caused wilting of millions banana clusters in several provinces. It is very difficult to control the disease due to the base data about ecology and epidemiology of the pathogen are still poorly understood. This research aimed to evaluate the effect of wounding of inoculation site on blood disease progress of plantain. The experiment was arranged using randomized completely block design It was conducted at three locations with altitude of 100, 1000, and $1600 \mathrm{~m}$ above sea levels as replication block. The treatments were wounding, unwounding inoculation site, inoculation, and uninoculation of plantain cv. Kepok Kuning Wounding was applied by stabbing with an injection pin around the corm of $15 \mathrm{stabs} / \mathrm{seedling}$. The seedlings were planted singly in one liter of non sterile soil in plastic bag. Each treatment consisted of 5 seedlings which was replicated 3 times. Inoculation was done by soil drenching of 20 $\mathrm{ml}$ bacterial suspension at concentration of $10^{8} \mathrm{cfu} / \mathrm{ml}$ two week after planting. The pathogen used for inoculation originated from low land area (about $100 \mathrm{~m}$ above sea level). Observation was done weekly for 5 weeks. The variables observed were wilt intensity and area under disease progress (AUDPC). The results showed that blood disease was able to establish at altitude of $1600 \mathrm{~m}$ above sea level. The disease progress however was slower that those at 100 and $1000 \mathrm{~m}$ above sea level. On wounded seedling, the disease progress was more aggressive than those on unwounded one.
\end{abstract}

Key wards: blood disease bacterium (BDB), plantain, ecology

\section{INTRODUCTION}

Blood disease is a major obstacle of banana and plantain production in Indonesia (Supriadi, 2005). The causal agent of the disease is called Blood Disease Bacterium (BDB). Formerly it was called Pseudomonas celebensis by Gauman and used reinstatement by Eden-Green et al. (1988), but it is no longer valid (Supriadi, 2005). In the field, the pathogen is highly virulent in cooking banana (ABB group) varieties (Eden-Green, 1994) but in artificially inoculation other varieties (desert banana, AAA group) the pathogen are virulent as well (Sudirman \& Supeno, 2002). Currently the disease had been reported in $90 \%$ (27 of 30 ) provinces Indonesia with disease incidence varies 10.000's to 1.000.000's clusters (Anonymous, 2006, Subandiyah et al. 2006). Certain districts in which $\mathrm{ABB}$ group were planted such as Bondowoso and Lombok, were extremely serious. The disease incidence reach more than 80 percent (Mulyadi \& Hernusa, 2002; Supeno, 2002; Supriadi, 2005).

Blood disease is still difficult to control due to poor fundamental knowledge about ecology and epidemiology of the disease. For example, how long the pathogen survive in soil, whether the pathogen associate with root systems of non-host plants, and whether widespread is the problem in naturally occurring Helliconia and Musa spp. It is obvious that in-depth studies on the ecology and epidemiology of blood disease bacterium of banana is urgently required (Fegan, 2005). How the role of wounding in infection process and how the effect of altitude on blood disease progress are two important aspects having not been studied yet as well.

The aim of the research is to evaluate the effect of altitude and wounding inoculation site of plantain seedlings to blood disease progress.

\section{MATERIALS AND METHODS}

The experiment was arranged using randomized completely block design. It was conducted at three locations with altitude of 100,1000 , and $1600 \mathrm{~m}$ above sea levels as replication block. The treatments were wounding, unwounding, inoculation, and uninoculation seedlings of plantain cv. Kepok Kuning. Wounding was applied by stabbing with a syringe

\footnotetext{
${ }^{1}$ Agronomy Department, Faculty of Agriculture, University of Sebelas Maret, Surakarta, Indonesia,

${ }^{2}$ Plant Protection Department, Faculty of Agriculture Gadjah Mada University, Yogyakarta, Indonesia,

${ }^{3}$ School of Molecular and Microbial Sciences and The Cooperative Research Center for Tropical Plant Protection, University of Queensland, St. Lucia 4072 Australia
} 
injection pin around the corm of 15 stabs. The seedlings were planted singly in one liter of non sterile soil in plastic bag. Each treatment consisted of 5 seedlings which was replicated 3 times. Inoculation was done by soil drenching of $20 \mathrm{ml}$ bacterial suspension at concentration of $10^{8} \mathrm{cfu} / \mathrm{ml}$ two week after planting. The pathogen used for inoculation originated from low land area (about $100 \mathrm{~m}$ above sea level). Wounding was applied by stabbing of syringe injection pin around the corm of 15 stabs/seedling. Wilt intensity was observed as dependent variables that were assessed weekly for 5 weeks. Wilt intensity was assessed using:

$$
I=\frac{\sum(n x v)}{N x V} \times 100 \%
$$

where $\mathrm{I}=$ wilt intensity $(\%) ; \mathrm{n}=$ number of plants with respective disease rating; $\mathrm{v}=$ disease rating $(0,1,2,3$, or 4); $\mathrm{N}=$ the number of plants observed; and $\mathrm{V}=$ the highest disease rating (4). Disease ratings used in the observation consist of: $0=$ no symptoms; $1=$ one leave wilted; $2=$ two leaves wilted; $3=$ three leaves wilted and $4=$ whole plant wilted (dead plant). This was modified from the rating system of Winstead and Kelman (1952).

Then the periodical data were used to calculate AUDPC (Area Under Disease Progress Curve) using formulation as following :

$$
A U D P C=\sum_{n-1}^{i=1}\left[\frac{X_{i}+X_{i+1}}{2}\right] x t_{i+1}-t_{i}
$$

where $\mathrm{X}=$ wilt intensity, $\mathrm{t}=$ times.

In addition, weather, $\mathrm{Rh}$ and temperature in which the trials were held were read three times daily (at 06.00, 12.00, and 18.00 o'clock) using Thermo hygrometer and temperature of soil using Mercury Thermometer. The growth variables were observed weekly for 35 days after transplanting on control unwounded-uninoculated seedlings. The height of plant was measured from the basal pseudostem to the highest leaf.

The data were analyzed with linier regression of wilt intensity and AUDPC as dependent variable. The first used a model $Y=a+b_{1} X_{1}+b_{2} X_{2}+D_{1}$ where $Y=$ wilt intensity (\%), $\mathrm{X}_{1}=$ time of observation, $\mathrm{X}_{2}=$ altitude ( $\mathrm{m}$ above sea level) and $D_{1}=$ dummy variable of wounding. The second used a model $Y=a+b_{1} X_{1}+D_{1}$ $\mathrm{Y}=$ AUDPC, $\mathrm{X}_{1}=$ altitude ( $\mathrm{m}$ above sea level) and $\mathrm{D}_{1}=$ dummy variable of wounding. For analyzing cumulative and single effect of independent variables to dependent variable were used F-test and t-test respectively. The data of growth and weather were analyzed using t-test pair mean comparison.

\section{RESULTS}

The results showed that wilt intensities caused by BDB were slightly affected by the altitudes in which the climates were different. Up to $1600 \mathrm{~m}$ above sea level, artificial inoculation of BDB was able to infect plantain seedling and the disease was still establish. In higher land however, the blood disease progress was slower.

Based on the regression analysis, altitude and wounding on plantain seedling significantly increased wilt intensity and AUDPC (Fig. 1, Table 1). The effect of wounding on the progress of blood disease were showed on all levels of altitude.

The results suggested that the blood disease progress on higher altitude of land and especially on unwounded seedling was more progressive than those at the middle and lower altitude of lands. Possibly, it is related to stressed seedling at the higher altitude of land. In facts, the air temperature and relative humidity were various from three levels of altitude (Table 2) by which the plantain growth were effected. The growth of uninoculated-unwounded seedlings at the middle and high altitude of land was retarded and even more at higher land (Table 3 ).

\section{DISCUSSION}

Most meteorological parameters are affected by topography. Altitude determines environmental conditions especially the climates or the weathers in an agriculture ecosystem including soil climates. The soil climate is essentially resulted from the interaction of three components: temperature, humidity, and aeration of soil. average, air temperatures decrease about $0.6^{\circ} \mathrm{C}$ per $100 \mathrm{~m}$ ascent (Seemann et al., 1979).

The results showed that the blood disease progress was more favorable at the lower land in which the soil temperature was higher. 


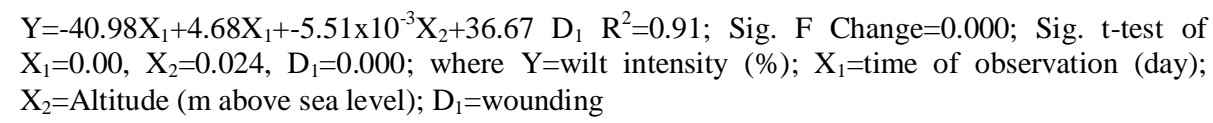
$\mathrm{X}_{2}=$ Altitude ( $\mathrm{m}$ above sea level); $\mathrm{D}_{1}=$ wounding

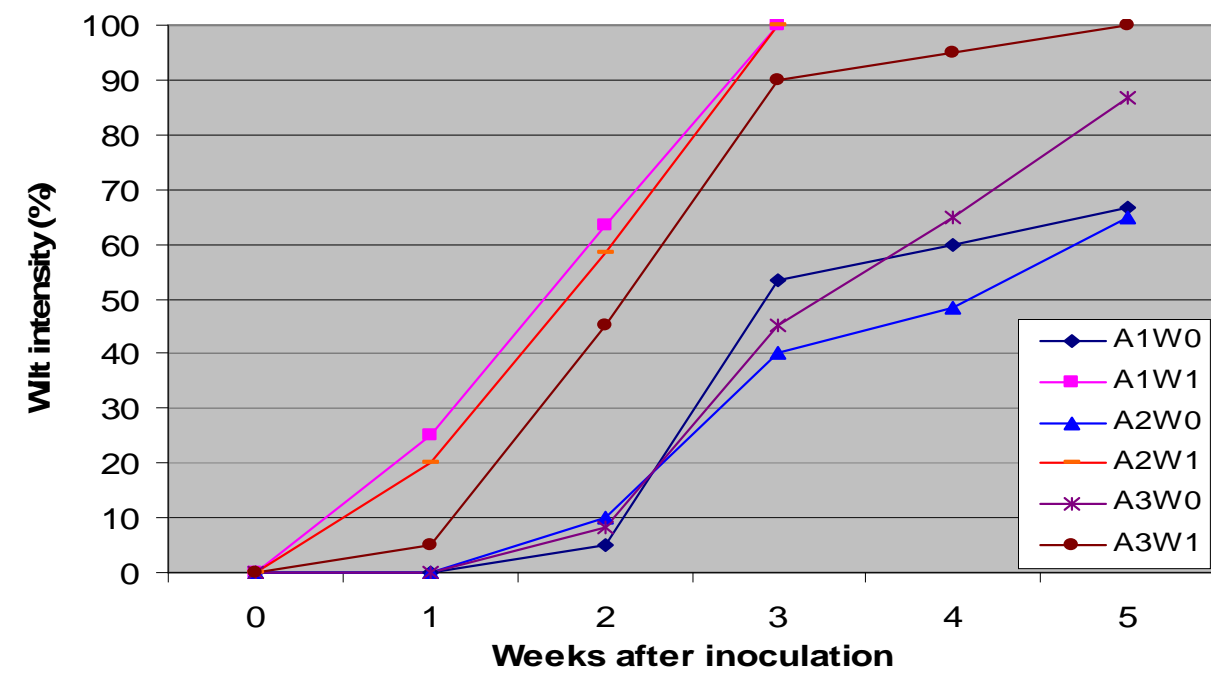

Note: A1. 100, A2. 1000, A3.1600 m above sea level; WO.unwounding and W1. wounding

Fig.1. The effect of wounding treatment on plantain seedling to wilt intensity at three levels of altitude in AprilMay 2006

Table 1. Effect of altitude and wounding to AUDPC of blood disease for 0-3 and 0-5 weeks after inoculation plantain seedling.

\begin{tabular}{lcccc}
\hline & \multicolumn{3}{c}{ AUDPC (weeks after inoculation) } \\
\cline { 2 - 5 } $\begin{array}{c}\text { Treatments: Altitude and } \\
\text { Wounding }\end{array}$ & \multicolumn{2}{c}{$\mathbf{0 - 3}$} & \multicolumn{2}{c}{$\mathbf{0 - 5}$} \\
\cline { 2 - 5 } & Uninoculated & Inoculated & Uninoculated & Inoculated \\
\cline { 2 - 5 } & & & & \\
Low land, 100 m above sea level & 0.00 & 211.67 & 0.00 & 1061.67 \\
$\quad$ Unwounded seedling & 0.00 & 968.33 & 0.00 & - \\
$\quad$ Wounded seedling & & & & \\
Middle land, 1000 m above sea level & 0.00 & 210.00 & 0.00 & 915.83 \\
$\quad$ Unwounded seedling & 0.00 & 898.33 & 0.00 & - \\
$\quad$ Wounded seedling & & & & 1131.67 \\
High land, 1600 m above sea level & 0.00 & 215.83 & 0.00 & - \\
$\quad$ Unwounded seedling & 0.00 & 665.00 & 0.00 & \\
$\quad$ Wounded seedling & & & & \\
\hline
\end{tabular}

Results of Regression analysis: $\mathrm{Y}=302.29-0.068 \mathrm{X}_{1}+614.92 \mathrm{D}_{1} \mathrm{R}^{2}=0.97$; Sig. $\mathrm{F}$ change $=0.000$; Sig. t-test of $\mathrm{X}_{1}=0.046, \mathrm{D}_{1}=0.000$ where $\mathrm{X}_{1}=\mathrm{AUDPC}, \mathrm{D}_{1}=$ altitude ( $\mathrm{m}$ above sea levels) 
Table 2. Daily Relative humidity, air and soil temperature on April-May 2006

\begin{tabular}{|c|c|c|c|c|c|c|}
\hline \multirow{3}{*}{ Altitude } & \multirow{2}{*}{\multicolumn{2}{|c|}{$\begin{array}{c}\text { Air Relative } \\
\text { Humidity, Rh }(\%)\end{array}$}} & \multicolumn{4}{|c|}{ Temperature ${ }^{\circ} \mathrm{C}$} \\
\hline & & & \multicolumn{2}{|c|}{ Air } & \multicolumn{2}{|c|}{ Soil Media } \\
\hline & Range & Average $^{1}$ & Range & Average $^{1}$ & Range & Average $^{1}$ \\
\hline $\begin{array}{l}\text { Low land, } \\
100 \text { a.s.l. }\end{array}$ & $52-91$ & $\begin{array}{r}68.10 \\
\pm 5.39 \mathrm{a}\end{array}$ & $22-34$ & $\begin{array}{c}26.22 \\
\pm 3.42 \mathrm{a}\end{array}$ & $20-39$ & $\begin{array}{c}29.01 \\
\pm 5.39 \mathrm{a}\end{array}$ \\
\hline $\begin{array}{l}\text { Middle Land, } \\
1000 \text { a.s.l. }\end{array}$ & $60-95$ & $\begin{array}{c}73.46 \\
\pm 4.08 \mathrm{~b}\end{array}$ & $20-30$ & $\begin{array}{l}24.70 \\
\pm 3.8 \mathrm{~b}\end{array}$ & $18-31$ & $\begin{array}{c}24.16 \\
\pm 1.15 \mathrm{~b}\end{array}$ \\
\hline $\begin{array}{l}\text { High Land, } \\
1600 \text { a.s.1 }\end{array}$ & $65-98$ & $\begin{array}{r}91.65 \\
\pm 5.88 \mathrm{c}\end{array}$ & $10-25$ & $\begin{array}{r}20.22 \\
\pm 2.63 \mathrm{c}\end{array}$ & $9-21$ & $\begin{array}{c}16.57 \\
\pm 0.99 \mathrm{c}\end{array}$ \\
\hline
\end{tabular}

Table 3. Plant height and weight of plantain seedling, cv. Kepok Kuning at three levels of altitude on 35 days after transplanting (April-May 2006)

\begin{tabular}{lccc}
\hline \multirow{2}{*}{ Altitude } & \multirow{2}{*}{ Height of $^{\mathrm{a}}$ Seedling } & \multicolumn{2}{c}{ Weight of $^{\mathrm{a}}$} \\
\cline { 3 - 4 } & & Fresh Plant & Dry Plant \\
\hline Low land, 100 a.s.l. & $48.86 \mathrm{a}$ & $76.86 \mathrm{a}$ & $25.94 \mathrm{a}$ \\
Midle Land, 1000 a.s.l. & $44.14 \mathrm{~b}$ & $57.85 \mathrm{~b}$ & $14.70 \mathrm{~b}$ \\
High Land, 1600 a.s.1 & $42.67 \mathrm{c}$ & $36.90 \mathrm{c}$ & $7.73 \mathrm{c}$ \\
\hline
\end{tabular}

${ }^{a}$ means of 15 seedlings and the means followed by the same letters are significantly indifferent at confidence of $95 \%$ according to $\mathrm{t}$-test analysis.

Buddenhagen (1961) reported that the bacterial wilt of banana was caused by $R$. solanacearum race 2 strain distributed in some countries in which as temperature and humidity are high. Goto (1992) stated that the temperature for optimum growth of plant pathogenic bacteria usually fall within the range of 25 to $30^{\circ} \mathrm{C}$. Whereas Buddenhagen and Kelman (1964) mentioned that Moko disease caused by $R$. solanacearum race 2 developed aggressively at range of temperature of 25 to $35^{\circ} \mathrm{C}$. It was reported that the $R$. solanacearum race 2 is closely related to blood disease bacteria (Seal et al. 1992; Eden-Green, 1994; Prior and Fegan, 2005; Fegan and Prior, 2006).

At $1600 \mathrm{~m}$ a.s.l. in which air temperature was the lowest and relative humidity was the highest, blood disease progress was still establish. It means that the environmental conditions were still favorable to blood disease infecton, although the wilting rate was the lowest. In its comparing with blood disease progress at the lower altitude however the disease progress at the high land was more aggressive on period of 3-5 weeks after inoculation. Possibly, the increase of blood disease progress at $1600 \mathrm{~m}$ a.s.l. was rather effected by environmental stress especially low temperature on the seedling than by the blood disease bacterium showed that at $1600 \mathrm{~m}$ a.s.l. the growth of plantain seedlings were retarded. The environmental stress can predispose plant to infection of some pathogens (Agrios, 2005).

Plant pathogenic bacteria enter the host plants through wounds and natural opening but not by direct penetration of non injured tissues (Danniels, 1992; Goto, 1992; Agrios, 2005). In this research the wounding of corm of plantain seedling improved infection of BDB. Goodman (1982) explained that injury of host is integral to initial phase of infection process of phytopathogenic bacteria. Although many bacteria cause infection by penetrating natural opening, seemingly some species of phytopathogenic bacteria parasitize the host more successfully, i.e. 
more uniformly and intensively through a wound site of even minute proportion. All plant parts are likely to be injured by variety of causes such as insects, wind, farming practices such as pruning, and mechanical damage due to agricultural machinery. The wounds utilized by the bacteria may be fresh or old and may consist of lacerated or killed tissue. These injuries are usually visible and constitute the major portals of entry for most bacterial plant pathogens. However, the wounds, that may not visible, can also become important sites of bacterial infection (Goto, 1992; Agrios, 2005).

In this research was used no sterile soil thus possibly soil microorganisms involved in natural wounding of seedling. Bolton et al. (1993) explained that injured roots may be due to microbial attack (detrimental microbes) and natural slough of root cap cells. Rhizoplane is usually inhabited by a lot of rhizobacterium. The some bacteria lyse and invade epidermal and cortical cells of the roots with invisible symptoms, but sometime no effect on plant growth. The detrimental rhizobacteria are called deleterious bacteria (Cook \& Baker, 1983; Kloepper, 1993,).

\section{CONCLUSIONS}

The present study showed that blood disease progress was still able to establish at altitude of 1600 $\mathrm{m}$ above sea level. The progress of blood disease however, was slower than at $100 \mathrm{~m}$ and $1000 \mathrm{~m}$ above sea level. On wounded seedling, the disease progress was more aggressive than those on unwounded seedling.

\section{ACKNOWLEDGEMENTS}

The authors would like to thank ACIAR (Australian Center for International Agriculture Research of project ACIAR CP/2004/034) for supporting the research funding.

\section{LITERATURES CITED}

Agrios, G.N. 2005. Plant Pathology. $4^{\text {th }}$ Ed. Elsevier Academic Press. Sandiego California. 922p.

Anonymous. 2006. Pola penyebaran OPT pada Tanaman Buah. Direktorat Jenderal Hortikultura.Jakarta. htt//:www.deptan.go.id/ditlinhorti/

peta_2005.htm. Accessed on 30 December 2006.

Bolten, H., Jr., J.K. Fredicktion, \& L.F. Elliot. 1993. Microbial ecology of the rhizosphere p.27-63 in: F.B. Metting, Jr. (ed). Soil Microbial Ecology; Applications in Agricultural and Environmental Management. Marcel Dekker, Inc. New York,

Buddenhagen, I.W. 1961. Bacterial wilt of bananas: history and known distribution. Trop. Agriculture 38(2):108-121.

Buddenhagen, I.W. \& A. Kelman. 1964. Biological and physiological aspects of bacterial wilt caused by Pseudomonas solanacearum. Ann. Rev. Pythopathol. 2:2003-230.

Cook, R.J. \& K.F. Baker. 1983. The Nature and Practice of Biological Control of Plant Pathogens. The American Phytopathological Society, St. Paul, Minnesota. 539 p.

Brown, J.F. 1997. Plant pathology: an overview Pp.320 In: J.F. Brown \& H.J. Ogle (eds). Plant Pathogens and Plant Diseases. APPS. Armidale, Australia.

Danniels, M.J. 1992. Bacteria. Pp.35-44 in: S.J. Gurr, M.J. McPherson, \& D.J. Bowles (eds). Molecular Plant Pathology. Vol.I: A Practical Approach. Oxford University Press. New York.

Eden-Green, S.J. 1994. Diversity of Pseudomonas solanacearum and related bacteria in South East Asia: new direction for Moko Disease. Pp.35-57 in: A.C. Hayward \& G.L Hartman (eds) Bacterial Wilt: the Disease and its Causative Agent, Pseudomonas solanacearum. CAB International.

Eden-Green, S.J., Supriadi, \& S.Y. Hastati. 1998. Characteristics of Pseudomonas celebensis, the cause of blood disease of banana in Indonesia. P.389 in: Proceedings of the $5^{\text {th }}$ International Congress of Plant Pathology, August 20-27, Kyoto, Japan. (Abstract). 
Fegan, M. \& P. Prior. 2006. Diverse members of Ralstonia solanacearum species complex cause bacterial wilts of banana. Australian Plant Pathol. 35(2):95-101.

Goodman, R.N. 1982. The infection process. Pp.3262 in: M.S. Mount and G.H. Lacy (eds). Phythopathogenic Prokaryotes. Vol.I Academic Press. New. New York.

Goto, M. 1992. Fundamental of Bacterial Plant Pathology. Acadmic Press, Inc. Sandiego, California. 339p.

Kloeper, J.W. 1993. Plant growth-promoting rhizobacteria as biological control agent. Pp.255-274 in: in: F.B. Metting, Jr. (ed). Soil Microbial Ecology; Applications in Agricultural and Environmental Management. Marcel Dekker, Inc. New York.

Muharom, A. \& Subijanto. 1991. Status of banana disease in Indonesia. p.44-49 in: Banana Disease in Asia and Pacific. Proceeding of Technical Meeting on Diseases Affecting Banana and Plantain in Asia and The Pacific, Brisbane, Australia., $15^{\text {th }}-18^{\text {th }}$ Augustus 1991.

Mulyadi \& T. Hernusa, 2002. Intensitas penyakit darah pada tanaman pisang yang disebabkan bakteri Pseudomonas solanacearum di Kabupaten Bondowoso. Pp.304-305 dalam: Prosiding Kongres XVI dan Seminar Nasional Perhimpunan Fitopatologi Indonesia. Jur. HPT F. Pertanian IPB, PFI, Bogor.

Prior, P. \& M. Fegan. 2005. Diversity and molecular detection of Ralstonia solanacearum ras 2 strains by multiplex PCR. Pp.405-414 in: C. Allen, P. Prior, and A.C. Hayward (eds). Bacterial Wilt Disease and the Ralstonia solanacearum Species Complex. APS Press. St. Paul, Minnesota USA
Seal, S.E., L. Jackson \& M.J. Danniels. 1992. Use tRNA consensus primers to indicate subgroups of Pseudomonas solanacearum by Polymerase cahain reaction amplification. Applied Environ. Microbiol. 58:3759-3761.

Seamann, J., Y.I Chirkoy, J. Lomas, \& B. Primaoult. 1979. Agroclimatology. Springer. Berlin Heidelberg. New York, 124p.

Subandiyah, S., Hadiwiyono, E. Nur, A. Wibowo, M. Fegan, \& P. Taylor. 2006. Survival of blood disease bacterium of banana soil. p.76-77 in: Proceeding of the 11st International conference on Plant Ptahogenic bacteria. $10^{\text {th }}$ to $14^{\text {th }}$ July 2006. Royal College of Physicians of Edinbrgh, Edinburgh, Scotland United Kingdom.

Sudirman \& B. Supeno. 2002. Skrining beberapa varietas pisang terhadap infeksi penyakit darah pisang. p.311-312 dalam: Prosiding Kongres XVI dan Seminar Nasional Perhimpunan Fitopatologi Indonesia. Jur. HPT F. Pertanian IPB, PFI, Bogor.

Supeno, B. 2001. Isolasi dan karakterisasi penyakit darah pisang di Lombok. Pp.31-33 dalam: Prosiding Kongres XVI dan Seminar Nasional Perhimpunan Fitopatologi Indonesia. Jur. HPT F. Pertanian IPB, PFI, Bogor.

Supriadi. 2005. Present status of blood disease in Indonesia. Pp. 395-404 in: C. Allen, P. Prior, and A.C. Hayward (eds). Bacterial Wilt Disease and the Ralstonia solanacearum Species Complex. APS Press. St. Paul, Minnesota USA.

Winstead, N.N. \& A. Kelman. 1952. Inoculation techniques for evaluating reinstance to Pseudomonas solanacearum. Phitopathology 42:628-634. 